\title{
STUDIA HISTORICA GEDANENSIA
}

TOM XI (2020)

\author{
Ireneusz Milewski \\ (Wydział Historyczny, Uniwersytet Gdański) \\ https://orcid.org/0000-0001-5743-8060
}

\section{Ekonomiczne aspekty funkcjonowania nosokomeionów we wczesnym Bizancjum ${ }^{1}$}

Słowa klucze: szpitale we wczesnym Bizancjum, gospodarka wczesnobizantyńska, hagiografia wczesnobizantyńska, pieniądz

Keywords: hospitals in early Byzantium, early Byzantine economy, early Byzantine hagiography, money

Jednym z elementów, które chrześcijaństwo wniosło do cywilizacji antycznej, było przykazanie miłości bliźniego oraz obowiązek jego praktykowania przez wiernych, od udzielania różnorakiej pomocy materialnej po uczynki niewymagające nakładów finansowych. W literaturze starochrześcijańskiej, a w większości wyszła ona spod pióra duchownych, propagowano równoważność obydwu tych form miłosierdzia. Ważne było, aby wspierać bliźniego w potrzebie, nie narzucając ani formy, ani też skali tego działania ${ }^{2}$. Nie znaczy to jednak, że nie próbowano w różnoraki sposób zachęcać potencjalnych darczyńców do większej ofiarności, choćby stwierdzeniami, że nierzadko ofiarują oni zaledwie z tego, co i tak im zbywa, albo też, że praktykowanie przykazania miłości, wsparcie bliźniego datkiem to swego rodzaju „dobrze zainwestowany kapitał”, który miłosiernemu chrześcijaninowi przyniesie stukrotne procenty niebieskie, innymi słowy - niewspółmierne do nakładów „korzyści” na Sądzie Ostatecznym. Odwoływanie się w takim przypadku do mechanizmów charakterystycznych dla transakcji finansowych jest znamienne dla całej literatury starochrześcijańskiej³

1 Artykuł powstał w ramach prac nad projektem finansowanym przez Narodowe Centrum Nauki (UMO-2015/17/B/HS3/00135).

2 Martin Wacht, „Krankenfürsorge”, Reallexikon für Antike und Christentum (Stuttgart: Anton Hierseman, 2006), 876; Ch. Gnilka, „Altersversorgung”, Reallexikon für Antike und Christentum, Supplement 1 (Stuttgart: Anton Hierseman, 1985), $286 \mathrm{ff}$.

3 Por. Juliusz Jundziłł, Pieniądz w łacińskiej literaturze chrześcijańskiej późnego Cesarstwa Rzymskiego (Warszawa: Wydawnictwo Akademii Teologii Katolickiej, 1984); Ireneusz Milewski, Pieniądz 
U schyłku antyku, w epoce intensywnego wspierania Kościoła przez państwo, praktykowaniu przykazania miłości nadano nową formę organizacyjną, zakładając szpitale oraz inne instytucje dobroczynne. Oczywiście, były one znane cywilizacji grecko-rzymskiej, choć na znacznie mniejszą skalę ${ }^{4}$. Chrześcijaństwo nadało im jednak nową formę organizacyjną, a przede wszystkim rozbudowało szpitalnictwo do niespotykanych wcześniej rozmiarów. W IV w. pojawiło się kilka rodzajów chrześcijańskich instytucji dobroczynnych, choć w praktyce różnice pomiędzy nimi były dość płynne. W zależności od potrzeby funkcję szpitala pełniły ksenodochia ( $w$ pierwotnym swym znaczeniu stanowiły one zajazdy dla podróżnych - domy pielgrzymów), ptochotrophia (przytułki dla ubogich), gerokomia (domy starców), a przede wszystkim wyspecjalizowane w opiece nad chorymi nosokomia ${ }^{5}$. Także ówczesny kościelny ustawodawca nie rozgraniczał tych instytucji, określając chociażby mianem ksenodochosa administratora szpitala ${ }^{6}$. Podobnie było również w przypadku ustawodawcy świeckiego ${ }^{7}$. Identyfikację „ksenonodocheionu” ze „szpitalem” w świecie bizantyńskim potwierdza również Jerzy Kedrenos. Opisując panowanie Tyberiusza I Konstancjusza (578-582), zachwala on działalność fundacyjną cesarza i stwierdza, że ufundowane przez niego zajazdy dla podróżnych pełniły również funkcje szpitali ${ }^{8}$. Innymi słowy, jako że chory, ubogi albo też zdrożony podróżny, bez względu na wiek, mógł znaleźć schronienie lub pomoc w każdej z wymienionych powyżej instytucji, w powszechnym odbiorze postrzegano je jako tożsame ${ }^{9}$. Posiadane przez nas

w greckiej literaturze patrystycznej czwartego wieku (na przykładzie pism Kapadockich Ojców Kościoła i Jana Chryzostoma) (Gdańsk: Wydawnictwo Uniwersytetu Gdańskiego, 1999).

4 Otfried Deubner, Das Asklepieon von Pergamon (Leipzig: Kunstwissenschaft, 1938); Hendrik Bolkestein, Wohltätigkeit und Armenpflege im vorchristlichen Altertum, Ein Beitrag zum Problem "Moral und Gesellschaft" (Groningen: Bouma's Boekhuis, 1967); Arthut Robinson Hands, Carities and Social aid in Greece and Rome (London: Thames and Hundson, 1968); Marina Elisabeth Pfeffer, Einrichtungen der sozialen Sicherung in der griechischen und römischen Antike unter besonderer Berücksichtigung der Sicherung bei Krankheit (Berlin: Duncker und Humboldt, 1969); Georg Harig, „Zum Problem Krankenhaus in der Antike”, Klio 53 (1971): 79-196; Joannes Demetrios Constantelos, Byzantine Philantropy and Social Welfare (New Brunswick: Rutgers University, 1968), 3-17; idem, „The Hellenic Background and Nature of Patristic Philantrophy in the Early Byzantine Era”, w Wealth and Poverty in Early Church and Society, ed. Susan Holman (Grand Rapids: Baker Academic, 2008), 187-210; Otto Hiltbrunner, „Krankenhaus”, Reallexikon für Antike und Christentum, Bd. 21 (Stuttgart, Anton Hiersemann, 2006), 882-891.

5 August Knecht, System des Justinianischen Kirchenvermögensrechtes (Amsterdam: Peter Schippers, 1963), 43-55.

6 Concilii Niceani, Canones arabici 75, w Mansi, Vol. II, spalta 1006. Por. także Constantelos, Byzantine Philantropy, 220.

7 Codex Iustinianus I, 2, 1, 19. Por. także Novellae Iustiniani 120, 6, oraz uwagi w Constantelos, Byzantine Philantropy, 159.

8 Georgius Cedrenus, Historiarum Compendium I, 690.

9 Alexandre Philipsborn, „Der Fortschrit in der Entwicklung des byzantinischen Krankenhauswesens”, Byzantinische Zeitschrift 54 (1961): 338; Peter Brown, Poverty and Leadership in the 
źródła nie zawsze dają jednak odpowiedź na pytanie, jak w praktyce kwestia ta była regulowana, już choćby tylko ze względów epidemiologiczno-sanitarnych, by zapobiec rozprzestrzenianiu się różnorakich chorób poprzez oddzielanie zakaźnie chorych od lżejszych przypadków. Jedynie w jednej z reguł Pachomiusza (Egipt, poł. IV w.), w zaleceniu dotyczącym funkcjonowania klasztornego ksenodochium czytamy, aby mnisi, poza samymi opiekunami, unikali kontaktu $\mathrm{z}$ chorymi przebywającymi w wydzielonej dla nich izbie, a z czasem, wraz $\mathrm{z}$ rozbudową klasztornej infrastruktury, w jego wydzielonym skrzydle ${ }^{10}$. Tym samym też dotykamy kolejnej kwestii, której pojawienie się u schyłku antyku było jednym z przejawów „chrystianizacji” przestrzeni miejskiej. Prowadzone przez Kościół instytucje dobroczynne, w tym szpitale ( $\mathrm{z}$ wyłączeniem leprosoriów, gdzie opiekowano się trędowatymi), z reguły były usytuowane w granicach miasta, najczęściej przy jednym z miejscowych kościołów, a nierzadko jedynym w mieście. $\mathrm{O}$ ile $\mathrm{w}$ przypadku przysłowiowych noclegowni nie był to jeszcze problem, o tyle już sprawa była bardziej złożona w przypadku szpitali oferujących opiekę nad biedakami obłożnie, a przede wszystkim nad zakaźnie chorymi. Z tego też względu „pogańskie” fundacje szpitalne usytuowane były poza skupiskami miejskimi, w zespołach świątynnych leżących na obrzeżach miast lub poza ich granicami (sanktuaria Asklepiosa-Esculapa) ${ }^{11}$, albo też na terenie wydzielonym, jak w przypadku lecznicy na insula Tiberina w Rzymie ${ }^{12}$. Innymi słowy, poza religijnymi to głównie względy sanitarne (z wyłączeniem lazaretów usytuowanych na terenie obozów legionowych ${ }^{13}$ ) decydowały o tym, że przez całą starożytność były one usytuowane na obrzeżach skupisk ludzkich. Późnoantyczny Kościół wraz ze swymi budynkami świątynnymi wkroczył natomiast do miast i już w nich pozostał1 ${ }^{14}$, wprowadzając coraz śmielej do tamtejszej przestrzeni noclegownie dla bezdomnych, także dla chorych. Co oczywiste, w tekstach wczesnobizantyńskich nie odnajdziemy żadnych negatywnych wypowiedzi na temat skutków przeniesienia szpitali do przestrzeni miejskiej. Także żadne z zachowanych do naszych czasów cesarskich rozporządzeń nie normuje kwestii sanitarnych związanych $\mathrm{z}$ funkcjonowaniem interesujących nas instytucji. A problem pewnie był, bo być musiał, tym bardziej na obszarach o klimacie panującym

Later Roman Empire (London: University Press of New England, 2002), 33; Peter Horden, „How Medicalised Were Byzantine Hospitals?”, Medicina e Storia 10 (2006): 45-74.

10 Regula Pachomii, ed. Jean-Paul Migne, Patrologia Graeca (dalej cyt. PG) 23 (Paris: 1883), 42; Wacht, „Krankenfürsorge”, 873-874; Hiltbrunner, „Krankenhaus”, 897.

11 Wacht, „Krankenfürsorge”, 829-830.

12 Carl Alfred Meier, Healing Dream and Ritual. Ancient Incubation and Modern Phychotheraphy (Einsiedeln: Daimon Verlag, 2003), 15.

13 Ralph Jackson, Doctors and Diseases in the Roman Empire (Oklahoma: University of Oklahoma Press, 1988), 133-137; Harald von Petrikovits, Die Innenbauten römischer Legionslager während der Prinzipatszeit (Wiesbaden: Springer Fachmedien Wiesbaden, 2013), 105-116, 146-147.

14 Ramsey MacMullen, „What Difference Did Christianity Make?”, Historia 35 (1986): 322-343; idem, „Cultural and Political Changes in the $4^{\text {th }}$ and $5^{\text {th }}$ Centuries”, Historia 52 (2003): 465-488. 
we wschodnich prowincjach Cesarstwa, gdzie dość szybko rozwijały się różnorakie choroby zakaźne, na które szczególnie byli podatni pielgrzymi z Zachodu (sami również stanowiący zagrożenie epidemiologiczne), od schyłku IV w. coraz liczniej przybywający do chrześcijańskich centrów pielgrzymkowych na Wschodzie. Innymi słowy, we wczesnobizantyńskich relacjach źródłowych odnajdziemy tylko pozytywne opisy takich instytucji, choć z brzmienia niektórych relacji można jednak wywnioskować, że ich funkcjonowaniu, głównie ze względów finansowych, czasami towarzyszyła również pewna patologia.

Informacje na temat wczesnobizantyńskiego szpitalnictwa odnajdujemy przede wszystkim w ówczesnych tekstach patrystycznych, hagiograficznych, papirusowych oraz w rozporządzeniach cesarskich, głównie z czasów Justyniana Wielkiego (527-565). Czy oznacza to, że działalność chrześcijańskich instytucji dobroczynnych $\mathrm{w} \mathrm{V}$ i na początku VI w. nie była unormowana? Wiele wskazuje na to, iż w tej mierze dano Kościołowi sporo swobody, a i sami biskupi dopiero na soborze chalcedońskim (451 r.) postanowili uregulować funkcjonowanie instytucji dobroczynnych, co jak wynika z treści kanonu normującego tę kwestię, było najprawdopodobniej związane z coraz częstszymi próbami zrzucenia, nie tylko nominalnego, biskupiego zwierzchnictwa przez zarządców tych instytucji, dysponujących coraz większymi środkami na ich funkcjonowanie ${ }^{15}$. Biskupstwa, nadzorujące na swym terenie różnorakie instytucje dobroczynne, otrzymywały na ten cel nierzadko spore środki, darowizny pieniężne oraz nieruchomości. Niektóre z tych zapisów czyniono również z myślą o konkretnych instytucjach dobroczynnych, co czasami generowało konflikty pomiędzy ich zarządcami a zwierzchnikami, lokalnymi biskupami, którzy nierzadko widzieliby zgoła inne przeznaczenia przekazanych sum (choćby rozbudowę lub modernizację siedziby biskupiej). Co oczywiste, w tekstach hagiograficznych czytamy również o biskupach, którzy wszelkimi sposobami zabiegali o gromadzenie funduszy na prowadzoną na terenie ich jurysdykcji działalność dobroczynną, w tym funkcjonowanie szpitali. Innymi słowy, skala działalności interesujących nas instytucji, wysokość obracanych przez nie sum pieniężnych oraz wielkość posiadanego majątku zadecydowały o tym, że związane $\mathrm{z}$ ich funkcjonowaniem kwestie ekonomiczne należało znormalizować w całym Cesarstwie. O ile w tekstach hagiograficznych relacjonowane są konkretne przypadki gromadzenia różnorakich dóbr materialnych umożliwiających funkcjonowanie przytułków i szpitali, to już nowele oraz konstytucje cesarskie normowały ten proces $\mathrm{w}$ skali całego państwa. Poniższe rozważania uszeregowane zostały w dwie grupy. Najpierw scharakteryzujemy pokrótce geograficzny zasięg fundacji szpitalnych na terenie Cesarstwa Bizantyńskiego od lat trzydziestych IV do początku VII w., następnie omówimy ekonomiczne aspekty ich funkcjonowania.

15 Concilium Chalcodonense, canon 8. Por. także Knecht, System, 44. 


\section{Geograficzny zasięg fundacji szpitalnych we wczesnym Bizancjum}

Geograficzny zasięg chrześcijańskich instytucji dobroczynnych w okresie wczesnobizantyńskim jest dość dobrze znany ${ }^{16}$, inaczej jest w wypadku próby oszacowania ich liczebności oraz wielkości. Gdybyśmy w tej mierze mieli zliczyć poszczególne fundacje wzmiankowane w źródłach oraz te znane $\mathrm{z}$ wykopalisk oraz oględzin terenowych, okazałoby się, że na obszarze całego Cesarstwa Wschodniorzymskiego do początku VII w. funkcjonowało zaledwie kilkadziesiąt tego typu instytucji, co bez wątpienia jest szacunkiem znacznie zaniżonym. Odnajdujemy je już od lat dwudziestych IV w. w Egipcie, a następnie na terenie Asia Minor, w Syrii, Palestynie oraz, co oczywiste, w stolicy Cesarstwa, Konstantynopolu. Chrześcijańskie instytucje dobroczynne powstawały przede wszystkim $\mathrm{w}$ wielkich skupiskach miejskich lub też, w przypadku wyspecjalizowanych ośrodków leczniczych, jak chociażby leprosoria (domy dla trędowatych), w ich okolicy ${ }^{17}$. Prowadzone one były przez miejscowych duchownych (prezbiterów, rzadziej diakonów) ${ }^{18}$, jak również przez mnichów, gdyż także monastycyzm coraz śmielej wkraczał do wczesnobizantyńskich miast.

\section{Fundacje szpitalne w Konstantynopolu}

Poza nieco legendarnymi fundacjami chrześcijańskich instytucji dobroczynnych, datowanymi jeszcze na lata trzydzieste IV w., na czasy Konstantyna Wielkiego oraz jego syna Konstancjusza II (ksenodochium Zoticosa oraz gerokomeion Flavii Heleny $)^{19}$, historycznie pewne są: ksenodochium założone i finansowane w latach czterdziestych IV w. przez miejscowego biskupa Macedoniusza ${ }^{20}$, instytucje dobroczynne, w tym szpitale, istniejące w połowie IV w., zarządzane przez diakona Maratoniusza ${ }^{21}$, oraz fundacje z końca IV w., o których wspomina Teodoret

16 Por. chociażby Stanisław Longosz, „Ksenodochium-hospicjum wczesnochrześcijańskie (nazwa, geneza, rozwój regionalny, struktura i organizacja)", Vox Patrum 16 (1996): 275-336 (szczególnie s. 289-321).

17 Gregorius Nazianzenus, Oratio 43, 63; Joannes Chrysostomus, Ad Stagyrium III, 13. Por. także Knecht, System, 47-48.

18 Joannes Chrysostomus, Ad Stagyrium III, 13; idem, De sacerdotio III, 12, 15.

19 Na temat wątpliwości wokół chronologii powstania wyżej wymienionych fundacji por. Constantelos, Byzantine Philantropy, 164-165.

20 Sozomenus, Historia Ecclesiastica IV, 20; Socrates, Historia Ecclesiastica II, 38; Chronicon Paschale, 545.

${ }^{21}$ Sozomenus, Historia Ecclesiastica IV, 20. W dalszej części swej relacji Sozomen wspomina, że Maratoniusz, zajmujący się uprzednio finansami w biurze prefekta pretorium, zgromadził pokaźny majątek, który następnie przeznaczył na funkcjonowanie konstantynopolitańskich instytucji dobroczynnych. Nie można wykluczyć, iż wspomniane fundacje są tożsame z tymi założonymi przez biskupa Macedoniusza, por. Constantelos, Byzantine Philantropy, 209-210. 
z Cyru, opisujący działalność dobroczynną Aelli Flacylli, żony Teodozjusza Wielkiego $^{22}$. Jeśli wierzyć Palladiuszowi z Helenopolis, fundatorem licznych instytucji dobroczynnych w Konstantynopolu oraz mecenasem już istniejących był Jan Chryzostom, biskup tego miasta w latach $398-404^{23}$. Na ten sam okres przypadaja fundacje kubikulariusza Lausosa ${ }^{24}$. O ile się orientuję w materiale źródłowym, odnotowujemy pojawienie się w V w. w Konstantynopolu zaledwie jednego nowego nosokomeionu (szpital pod wezwaniem śś. Kosmy i Damiana) ${ }^{25}$ oraz „ksenonu” ${ }^{26}$, co nie musi oznaczać, że nie powstawały wówczas kolejne. Stolica Cesarstwa Wschodniorzymskiego od czasów cesarza Arkadiusza stanowiła cel wielu „pielgrzymek" kościelno-politycznych, głównie na dwór cesarski, i niezmiennie leżała na jednym z głównych szlaków handlowych prowadzących ze Wschodu na Zachód oraz z Południa na Północ. Już choćby ta lokalizacja miała wpływ na przemieszczanie się przez miasto olbrzymich mas ludzi. Rozbudowująca się stolica Cesarstwa po osiedleniu się tam na stałe dworu przeżywała w V w. boom demograficzny, a w związku z nim również gwałtowny wzrost liczby bezdomnych. Pewnie więc wtedy powstały liczne chrześcijańskie instytucje dobroczynne, w tym szpitale. Ostatnia ze znanych fundacji szpitalnych $\mathrm{z}$ terenu Konstantynopola w okresie wczesnobizantyńskim datowana jest na czasy Justyniana, choć najpewniej ufundowano ją jeszcze za rządów cesarza Anastazjusza I (491-517). Mam tu na myśli tzw. ksenodochium Samsona, które pełniło również funkcję szpitala ${ }^{27}$. Justynian przekazał pokaźne sumy na rozbudowę tej instytucji, spalonej w czasie powstania Nika $(532 \text { r. })^{28}$. Z inicjatywy tego samego cesarza oraz w oparciu o przekazane przez niego fundusze w stolicy ufundowano wiele ksenodochejonów, gerokomeionów, orfanotrofiów ${ }^{29}$ oraz jeden nosokomeion ${ }^{30}$. Jak wyliczył Robert Janin, w stolicy Cesarstwa Bizantyńskiego można zidentyfikować co najmniej 61 chrześcijańskich instytucji dobroczynnych, w tym: 28 ksenodochiów, 27 domów starców oraz co najmniej sześć szpitali, funkcjonujących tam do 1453 r., kiedy

22 Theodoretus Cyriensis, Historia Ecclesiastica V, 19. Por. także Wacht, „Krankenfürsorge”, 872.

23 Palladius, Dialogus 5. Por. także Gilbert Dagron, Naissance d'une capitale. Constantinople et ses institutions de 330-451 (Paris: Presses Universitaires de Paris, 1974), 22; Constantelos, Byzantine Philantropy, 155-156; Wacht, „Krankenfürsorge”, 872-873; Hiltbrunner, „Krankenhaus”, 896.

24 Georgius Codinus-Ps., Patria Constantinopoleos, II, 170; Georgius Cedrenus, Historiarum Compendium I, 564.

25 Hilbrunner, „Krankenhaus”, 896.

26 Datowana na przełom lat 50. i 60. V w. fundacja Eutropiusza i Teodory, por. Symeon Metaphrastes, Vita s. Joannis Calybitae 1, Vita Sanctorum, PG 114.

27 Procopius, De aedificiis I, 2, 15; Georgius Codinus-Ps., Patria Constantinopoleos 99. Por. także Constantelos, Byzantine Philantropy, 162-182, 191-192.

28 Procopius, De aedificiis I, 2, 15; Chronicon Paschale 877 B; Constantelos, Byzantine Philantropy, 189; Hiltbrunner, „Krankenhaus”, 895-896.

29 Zestawienie tych fundacji por. Van Minnen, „Medical Care”, 159; Longosz, „Ksenodochium”, 292-293.

30 Ps. Georgius Codinus, De aedificiis 89. 
miasto zdobyli Turcy ${ }^{31}$. Pamiętajmy jednak, że w interesującym nas okresie domy dla podróżnych, gerokomia oraz ptochotrophia również pełniły funkcję szpitali.

\section{Fundacje szpitalne na terenie Asia Minor}

Jedną z najwcześniejszych, jeśli nie najwcześniejszą chrześcijańską fundacją szpitalną na tym obszarze był „dom dla biednych” założony w połowie IV w. przez biskupa Eustacjusza w armeńskim Sebaste ${ }^{32}$. Kolejna fundacja jest datowana na początek lat siedemdziesiątych IV w. To tzw. Bazyliada, przedsięwzięcie zorganizowane przez Bazylego, biskupa Cezarei Kapadockiej. Ze względu na leczone w niej przypadłości (m.in. trąd), choć pewnie nie tylko, usytuowana ona była poza granicami miasta ${ }^{33}$. O tym, że instytucja ta istniała jeszcze w latach dwudziestych $\mathrm{V}$ w., a być może dłużej, czytamy u Sozomena ${ }^{34}$. Okres powstania fundacji to czas intensywnego wspierania Kościoła przez państwo (poza kilkunastoma miesiącami rządów Juliana Apostaty [361-363]), niemniej miasta nadal w większości pozostawały wówczas pogańskie. Doceniano co prawda dobroczynną stronę zakładania i prowadzenia tego typu instytucji przez Kościół, nie znaczyło to jednak, aby wbrew odwiecznym normom umożliwić ich działalność w granicach miasta. Ze względów epidemiologicznych, a czasami również religijnych, miejscowi chorzy, a już tym bardziej przyjezdni, mieli leczyć się poza jego murami lub przynajmniej na skraju miasta. Co ciekawe, Grzegorz, zachwalając dzieło Bazylego, nie posiadał analogicznej fundacji w mieście, w którym był biskupem, w Nazjanzos ${ }^{35}$. Kolejne fundacje szpitalne datowane na okres

31 Raymond Janin, La géographie ecclésiastique de l'empire byzantin. Première partie: Les églises et les monastères (Paris: Institut Etudes Byzantines, 1969), 552-567. Więcej na temat fundacji chrześcijańskich instytucji dobroczynnych w Konstantynopolu w okresie wczesnobizantyńskim por. m.in.: Kyrill Amantos, „Zu den wohltätigen Stiftungen von Byzanz”, Orientalia Christiana Periodica 21 (1955): 15-20; Dagron, Naissance d'une capitale, 510-514; Hiltbrunner, „Xenodocheion”, 1498-1499; Longosz, „Ksenodochium”, 289-293.

32 Epiphanius, Adversus Haereses III, 55 (75), PG 42. Por. także Longosz, „Ksenodochium”, 293.

33 Gregorius Nazianzenus, Oratio 43, 63; Gregorius Nyssenus, Oratio in laudem Basilii 7; Theodoretus Cyriensis, Historia Ecclesiastica IV, 16. Por. także Lucas Vischer, Basilius der Grosse. Untersuchungen $z$ u einem Kirchenvater des 4. Jahrhunderts (Basel: Buchdruckerei F. Reinhardt, 1953), 141-142; Constantelos, Byzantine Philantropy, 89-90, 154, 181-182; Van Minnen, „Medical Care”, 157-158; Logosz, "Ksenodochium”, 293-294; Timothy Miller, The Birth of the Hospital in the Byzantine Empire (Baltimore: John Hopkins University Press, 1997), 25-26, 85; Susane Hübner, Der Klerus in der Gesellschaft des spätantiken Kleinasiens (Stuttgart: Franz Steiner Verlag, 2005), 143; Timothy Patitsas, „St. Basil’s Philantropic and Modern Microlending Strategies for Economic Self-Actualization", w Wealth and Poverty in Early Church and Society, ed. Susan Holman (Grand Rapids: Baker Academics, 2008), 267-286; Susan Holman, The Hungry are Dying. Beggars and Bishops in Roman Cappadocia (Oxford - New York: Oxford University Press, 2001), 74-75; Raymond Van Dam, Kingdom of Snow. Roman Rule and Greek Culture in Cappadocia (Philadelphia: University of Pensylvania Press, 2002), 39-52.

${ }_{34}$ Sozomenus, Historia Ecclesiastica VI, 34.

35 Gregorius Nazianzenus, Oratio 14, 16. 
wczesnobizantyński usytuowane na terenie Asia Minor odnotowujemy w Ancyrze $\left(\text { Galacja) }{ }^{36} \text {, Efezie (Azja) }{ }^{37} \text {, Pithii (Bitynia) }\right)^{38}$, Emporium (Pamfilia) ${ }^{39}$, Mocesos (Kapadocja) ${ }^{40}$ oraz Side (Pamfilia). Z wymienionych powyżej najbardziej znana jest ostatnia. Powstały najpewniej w VI w. szpital zachował się dość dobrze do naszych czasów. To dwukondygnacyjny budynek, na który składa się pięć dużych podłużnych pomieszczeń, podzielonych na mniejsze sale, połączone ze sobą drzwiami wewnętrznymi. Zachowane ruiny szpitala pozwalają na określenie jego wymiarów: 27 na 16,5 metra. Ściany zewnętrzne zostały wzniesione ze spolia pozyskanych w okolicy, a pomieszczenia wyłożone kamieniem obrobionym specjalnie do tej inwestycji ${ }^{41}$.

\section{Fundacje szpitalne na terenie Syrii}

Pierwsze fundacje szpitalne w Syrii powstały w Antiochii, w największym i najbardziej schrystianizowanym mieście regionu. Są one datowane jeszcze na lata trzydzieste IV w., na czasy biskupa Leoncjusza. O ile w przypadku Antiochii, metropolii z pokaźnym odsetkiem chrześcijan, nie ma potrzeby kwestionować faktu założenia już wówczas instytucji dobroczynnej ${ }^{42}$, to już okoliczności jej założenia, opisane chociażby przez bizantyńskiego kronikarza Jana Malalsa oraz przez autora Chronicon Paschale ${ }^{43}$, należy uznać za niewiarygodne. Miało do tego dojść w czasie powrotu Konstantyna Wielkiego z wyprawy przeciwko Persji ${ }^{44}$, do której jednak nigdy nie doszło ${ }^{45}$. Jan Chryzostom (lata 80. IV w.) wspomina o istnieniu w Antiochii

36 Palladius, Historia Lausiaca 67, 2; Nilus Ancyranus, Epistula II, 110, III, 33; Vita Danielis Stylitae 8. Por. także Van Minnen, „Medical Care”, 159-160; Vivian Nutton, „From Galen to Alexander: Aspects of Medicine and Medical Practice in Late Antiquity", Dumbarton Oaks Papers 38 (1984): 9-10.

37 Concilium Chalcedonense, canones 21-22. Por. także Constantelos, Byzantine Philantropy, 157.

38 Procopius, De aedificiis I, 9. Por. także Constantelos, Byzantine Philantropy, 157; oraz Hiltbrunner, „Krankenhaus”, 900.

39 Procopius, De aedificiis V, 9. Por. także Hiltbrunner, „Krankenhaus”, 900.

40 Procopius, De aedificiis V, 4.

41 Por. uwagi na temat ruin wspomnianego powyżej szpitala w Side: www.turkisharchaeonews. net/object/byzantine-hospital-side, dostęp: 5 VII 2019. Więcej na temat fundacji chrześcijańskich instytucji dobroczynnych na terenie Asia Minor w okresie wczesnobizantyńskim por. Longosz, „Ksenodochium”, 293-296.

42 Glanville Downey, A History of Antioch in Syria from Seleukus to the Arab Conquest (Princeton - New Yersey: Princeton University Press, 1961), 349, 622, 650.

43 Chronicon Paschale, 535.

44 Jonnaes Malalas, Chronographia XIII, 318.

45 Por. przekaz na ten temat $\mathrm{w}$ Vita Constantini oraz ikonografia części bitego przez niego pieniądza po 324 r. (po pobiciu Licyniusza) wskazują, że cesarz rzeczywiście nosił się z zamiarem wyprawy przeciw Persom, por. Andreas Luther, „Konstains letzte Pläne. Die unvollendete Persienexpedition”, w Konstantin der Große zwischen Sol und Christus, hg. v. Kay Ehling, Gregor Weber (Mainz: Philip von Zabern, 2011), 110-117; Ireneusz Milewski, „Konstantynopol nowym Heliopolis? Uwagi do «wizji» 
ksenodochiów i ptochotrophiów, w których opiekę mogli znaleźć biedni, chorzy i podróżni ${ }^{46}$, oraz miejsc poza miastem przeznaczonych dla chorych na trąd ${ }^{47}$. W Antiochii, podobnie jak w Konstantynopolu, musiało funkcjonować wiele tego typu instytucji, niemniej dopiero na czasy Justyniana datowane są kolejne chrześcijańskie fundacje szpitalne $\mathrm{w}$ tym mieście ${ }^{48}$ oraz w jego okolicy (chociażby w Dafne) $)^{49}$.

Poza Antiochią, która z racji lokalizacji, liczby mieszkańców oraz napływających podrożnych obfitowała w różnorakie instytucje dobroczynne, spore skupisko ksenodochiów, pełniących również funkcję szpitali, odnotowujemy w pobliskim Telanissos, centrum pielgrzymkowym Szymona Słupnika ${ }^{50}$. Zaczęly one powstawać jeszcze za jego życia. Jak na początku lat pięćdziesiątych XX w. ustalił Georges Tschalenko (a o ile się orientuję, szacunków tych nikt dotąd nie zakwestionował), wokół kościoła-sanktuarium świętego męża funkcjonowało co najmniej 12 ksenodochiów ${ }^{51}$. Kolejne interesujące nas fundacje z terenu Syrii zlokalizowane zostały w Turmaninie (dobrze zachowany kompleks ksenodochiów dla pielgrzymów zmierzających do sanktuarium sławnego stylity w Telanissos) oraz w Tell Áqibrīnie (antyczne Tilokbarionos) $^{52}$. Fundacje szpitalne odnajdujemy również w Edessie ${ }^{53}$,

epoki konstantyńskiej w książce Rolfa Bergmeiera, Kaiser Konstantin und die wilden Jahre des Christentums. Die Legende vom ersten christlichen Kaiser, Aschaffenburg 2016 (zweite, korrigierte Auflage 2016), ss. 350", Studia Europaea Gnesnensia 19 (2019): 343-372.

46 Joannes Chrysostomus, In Matthaeum 66, 3 (opieka „nad trzystoma chorymi”); idem, Ad Stagyrium III, 13; idem, In Epistulam I ad Corinthios 21. Por. także Chronicon Paschale, 722. Por. także Knecht, System, 43; Constantelos, Byzantine Philantropy, 258-259; Wendy Mayer, „Poverty and Generosity toward the Poor in the Time of John Chrysostom", w Wealth and Poverty, 140-158.

47 Joannes Chrysostomus, In Hebraeos 15, 3.

48 Procopius, De aedificiis II, 10, 25. Por. także Malalas, Chronographia, 423, który wspomina o ufundowanym przez Justyniana ksenodochium z rocznym budżetem sięgającym 4 tys. solidów. Por. także Constantelos, Byzantine Philantropy, 212.

49 Evagrius, Historia Ecclesiastica IV, 35; Joanne Moschos, Pratum spirituale 88, PG 87, 3. Por. także Downey, A History of Antioch, 553-557.

50 Evagrius, Historia Ecclesiastica I, 14.

51 Georges Tschalenko, Vilages antiques de la Syrie du nord, Vol. 1 (Paris: Librairie Orientaliste Paul Geuthner, 1953), 208-210; 220; Bernard Kötting, Peregrinatio religiosa. Wallfahrt und Pilgerwesen in Antike und alter Kirche (Münster: Regensberg, 1950), 124-130; 220; Dietrich Claude, Die byzantinische Stadt im 6. Jahrhundert (München: C.H. Beck’sche Verlagsbuchhandlung 1969), 209-210, 212, 216, 218; Longosz, „Ksenodochium”, 330-333. George Tschalenko, „Notes on the Sanctuary of St. Symeon Stylites", w Notes on the Sanctuary of St. Symeon Stylites, ed. Emma Loosley-Leeming, John Tschalenko (Leiden-Boston-Köln: Brill, 2019), 39-42, 51-53.

${ }_{52}$ Tschalenko, „Notes on the Sanctuary”, 58.

53 Wśród tamtejszych fundacji dobroczynnych odnajdujemy: ksenodochium diakona Efrema „na 300 łóżek”, ufundowane w latach 70. IV w. (Sozomenus, Historia Ecclesiastica III, 16. Por. także Constaltelos, Byzantine Philantropy, 209), ksenodochium ufundowane przez miejscowego biskupa Rabulę w latach 30. V w. (Vita Rabulae 421, 443-444) oraz leprosorium ufundowane w latach 457-458 przez miejscowego biskupa Nonusa (Chronicon Edessenum 68). Por. także Constantelos, Byzantine Philantropy, 158-159. 
Apemei ${ }^{54}$, Bostrze $^{55}$ oraz Amidzie ${ }^{56}$. Już na pierwszy rzut oka widać, że w przypadku ludnej i dość schrystianizowanej prowincji, jaką była Syria, nie są to liczne fundacje. Nie przywiązywałbym jednak do tego zbyt wielkiej wagi. Bez obaw o przekłamanie założyć można, iż interesujące nas instytucje, w tym szpitale, licznie występowały wówczas na terenie całej Syrii.

\section{Fundacje szpitalne w Palestynie}

O pierwszych fundacjach dobroczynnych na terenie Palestyny, w tym przede wszystkim w Jerozolimie oraz jej okolicach, czytamy w listach Hieronima oraz u Palladiusza z Helenopolis ${ }^{57}$. W przypadku tej części Imperium szczególnie ważnym czynnikiem stymulującym rozwój interesujących nas instytucji były pielgrzymki do miejsc świętych, a skala ubóstwa czy też skutki przemian gospodarczo-społecznych, mających negatywny wpływ na kondycję materialną tamtejszej ludności, były zapewne porównywalne z innymi jego obszarami. Co ciekawe, posiadamy zaledwie jedną udokumentowaną źródłowo fundację ksenodochium w Jerozolimie do końca IV w..$^{58}$ Może to być ważki argument $\mathrm{w}$ dyskusji na temat Palestyny jako celu rzekomo licznych pielgrzymek chrześcijańskich już od czasów Konstantyna Wielkiego. Patrzymy na tę kwestię bardziej poprzez pryzmat wzmożonego ruchu pielgrzymkowego oraz licznych fundacji $\mathrm{w} \mathrm{V}^{59}$, a przede wszystkim w VI w., w czasach Justyniana ${ }^{60}$.

54 Procopius, De aedificiis V, 9, 27.

55 Ibidem.

56 Joannes Ephesinus, Historia beatorum orientalium, Patrologia Orientalis 17/1, 180. Więcej na temat fundacji chrześcijańskich instytucji dobroczynnych na terenie Syrii w okresie wczesnobizantyńskim por. Longosz, „Ksenodochium”, 296-299.

${ }_{57}$ Hieronymus, Epistula 108, 14; Palladius, Historia Lausiaca HL 54-55, 6. Por. także Michele Renee Salzmann, The Making of a Christian Aristocracy. Social and Religious Change in the Western Roman Empire (Cambridge-London: Harvard University Press, 2002), 24-26; Marlena Whiting, „Asceticism and Hospitality as Patronage in the Late Antique Holy Land. The Examples of Paula and Melania the Elder", w Female Founders in Byzantium and Beyond, ed. by Matthew Savage et al. (Wien: Böhlau Verlag, 2014), 73-84.

58 Peregrinatio Egeriae 25, 7.

59 Por. ksenodochium w Gazie ufundowane na początku V w. przez cesarzową Eudoksję, żonę Arkadiusza (Marcus Diaconus, Vita Porphyrii, episcopi Gazensis 94), fundacje dobroczynne (ksenodochia, przytułki szpitale) w Jerozolimie z V w., por. Gerontius, Vita Melaniae Iunioris 35 (fundacje Melanii Młodszej), fundacje biskupa Passariona (Hilbrunner, „Krankenhaus”, 899), Piotra Iberyjczyka (ok. 438 r., por. Vita Petri Iberi 35) oraz Aelii Eudokii, żony Teodozjusza II. Por. Cyrillus Scythopolitanus, Vita Euthymii 35, tłum. Ewa Dąbrowska (Kraków - Tyniec: Wydawnictwo Benedyktynów, 2011), 201, gdzie czytamy: „Błogosławiona Eudokia zbudowała wiele kościołów Chrystusowi i tak wiele klasztorów i przytułków, że nie jestem w stanie ich policzyć". Na temat jej działalności dobroczynnej por. także Evagrius Scholasticus, Historia Ecclesiatica I, 21-22; Nicephorus Callistus, Historia Ecclesiastica 14, 50. Por. także Konstantin Michael Klein, „Do good in thy good pleasure unto Zion. The Patronage of Aelia Eudokia in Jerusalem”, w Female Founders, 85-93; Hiltbrunner, „Krankenhaus”, 899.

${ }^{60}$ Procopius, De aedificiis V, 6, 25 (szpital przy miejscowym kościele pod wezwaniem Marii Matki Jezusa); Cyrillus Scythopolitanus, Vita Sabae 73; Anonymous Placentinus, Itinerarium 23. 
Pielgrzymi, którzy nierzadko po wielu miesiącach podróży docierali do Palestyny, byli z reguły wycieńczeni i chorzy, stąd konieczność roztoczenia nad nimi opieki. Co oczywiste, interesujące nas instytucje szpitalne powstawały również w innych częściach Palestyny. Wspomina o nich chociażby Cyryl ze Scytopolis (nosokomeion przy jednej z ławr mnicha Saby na Pustynii Judzkiej ${ }^{61}$ oraz bliżej nieokreślony szpital wybudowany przez mnicha Teodozjusza w okolicach Jerozolimy ${ }^{62}$ ), jak również Anonim z Piacenzy, wymieniający leprosorium w Gaderze „na trzysta łóżek”, rzekomo finansowane przez lokalne władze, oraz szpital u podnóża Góry Hermon, gdzie w dość osobliwy sposób wytwarzano „bardzo skuteczne” mikstury lecznicze ${ }^{63}$.

\section{Fundacje szpitalne w Egipcie}

Największą liczbę chrześcijańskich instytucji dobroczynnych odnotowujemy w Aleksandrii ${ }^{64}$ oraz jej okolicy ${ }^{65}$. Aleksandria to jedno z najludniejszych miast rzymskiego Wschodu. O rozwoju tamtejszych instytucji dobroczynnych decydowały tożsame czynniki, jak w przypadku Konstantynopola czy też Antiochii. Warto podkreślić, że chrześcijańskie instytucje dobroczynne w tym mieście, a konkretnie ich personel, były na początku $\mathrm{V}$ w. przedmiotem zainteresowania świeckiego ustawodawcy (o czym w drugiej części tekstu). Zastanawiający jest brak szerszych informacji na temat szpitali i innych instytucji dobroczynnych, a już tym bardziej ich fundowania w Aleksandrii w VI w. Jedyne znane przypadki to gerokomeion i nosokomeion ufundowane przez patriarchę Apollinariosa ${ }^{66}$ oraz ksenon w pobliżu wyspy Faros, usytuowany pomiędzy kościołami św. Zofii oraz św. Faustosa ${ }^{67}$. Powstanie kolejnych fundacji (nosokomia, ksenodochia i ptochotrophia) datowane jest dopiero na przełom VI i VII w., na okres, kiedy biskupem tego miasta był Jan Jałmużnik. Chronologia powstania tych instytucji nie jest przypadkowa. W tym właśnie czasie do Egiptu, a przede wszystkim do Aleksandrii, licznie napływali uciekinierzy z Syrii i Palestyny, nękanych perskimi najazdami ${ }^{68}$. Poza przytułkami i szpitalami biskup ufundował

Por. także ksenodochium w Ascalon; Joannes Moschos, Pratum spirituale 189, PG 87/3; Constantelos, Byzantine Philantropy, 159-160; Hiltbrunner, „Krankenhaus”, 899.

61 Cyrillus Scythopolitanus, Vita Sabae 32.

${ }^{62}$ Idem, Vita Theodosii 235-241. Por. także Constantelos, Byzantine Philantropy, 157-160; Philipsborn, „Fortschritt”, 348.

63 Anonymus Placentinus, Itinerarium 7-9. Por. także Kötting, Peregrinatio religiosa, 386; Claude, Die byzantinische Stadt, 228; Longosz, „Ksenodochium”, 300-303 (szczególnie 302); Hiltbrunner, „Krankenhaus”, 899.

64 Palladius Helenopolitanus, Historia Lausiaca 1,1.

65 Joannes Cassianus, Collationes Patrum XIV, 4, 2.

66 Symeon Metaphrastes, Vita ss. Cyri et Joannis 2, PG 114.

67 Jan Moschos, Pratum spirituale 106, PG 87,3.

68 Constantelos, Byzantine Philantropy, 74. 
również „siedem porodówek”, rzekomo każda na czterdzieści łóżek. Kobiety korzystające $\mathrm{z}$ ich opieki mogły tam przebywać przez siedem $\mathrm{dni}^{69}$. Szpitale i ksenodochia odnotowujemy również na egipskiej prowincji, przy coraz liczniej powstających wspólnotach monastycznych (pachomiańskich ${ }^{70}$ oraz innych $^{71}$ ), jak również $\mathrm{w}$ miejscowościach pielgrzymkowych, chociażby w sanktuarium św. Menasa ${ }^{72}$ oraz śś. Cyryla i Jana w Menuthis ${ }^{73}$. Cechą charakterystyczną szpitalnictwa chrześcijańskiego we wczesnobizantyńskim Egipcie jest spora liczba fundacji prywatnych, zakładanych i utrzymywanych przez zamożne rodziny, przede wszystkim przez Apionów, chociażby w Oxyrynchos, Leukadios, Aphrodito, Antinopolis, Arsinoe oraz w Hermopolis ${ }^{74}$. Według ustaleń Petera van Minnena w tym ostatnim mieście było co najmniej osiem, a niewykluczone, że nawet 16 szpitali $^{75}$, co, biorąc pod uwagę wielkość tego miasta, jest chyba liczbą zawyżoną.

Wyżej wymienione to wczesnobizantyńskie fundacje nosokomeionów oraz ksenodocheionów, pełniących także funkcje szpitalne, których lokalizacja jest znana. Co oczywiste, nie są to wszystkie tego typu instytucje funkcjonujące wówczas na terenie Cesarstwa Bizantyńskiego. $Z$ dużym prawdopodobieństwem można założyć, że każde centrum pielgrzymkowe posiadało co najmniej jedną tego typu instytucję, a większe z nich (jak chociażby sanktuarium Szymona Słupnika) oraz metropolie Cesarstwa posiadały ich kilka. Stąd też, szczególnie w realiach prowincjonalnych, brak rozróżnienia w zakresie świadczonych tam usług, choć ze względów praktycznych podzielone one były na oddziały lub co najmniej na pomieszczenia, w których mogli zatrzymać się na noc zdrożeni pielgrzymi lub inni podróżni, oraz te, w których przebywali chorzy.

${ }^{69}$ Leontios Neapoleos, Vita Joannis Elemosynarii 1, 6. Por. także Herbert Hunger, Das Reich der neuen Mitte (Graz: Verlag Styria, 1965), 178; Longosz, „Ksenodochium”, 305.

70 Regula Pachomii 50.

71 Palladius, Historia Lausiaca 14, 3.

72 Kötting, Peregrinatio religiosa, 189-201, 380-382; Claude, Die byzantinische Stadt, 210-211, 213; Longosz, „Ksenodochium”, 305; Timothy Miller, The Birth of the Hospital in the Byzantine Empire (Baltimore: Johns Hopkins University Press, 1997), 61 i n., 156 i n.; Peter Grossmann, Christliche Architektur in Ägypten (Leiden-Boston-Köln: Brill, 2002), 235-239.

73 Kötting, Peregrinatio religiosa, 201-211; Grossmann, Christliche Architektur, 237. Kolejne fundacje por. Claude, Die byzantinische Stadt, 213; Longosz, „Ksenodochium”, 306-307.

${ }_{74}$ Podstawowe informacje na temat ich działalności fundacyjnej por. Genevieve Husson, „L'hospitalité dans les papyrus byzantins”, w Akten des XIII. internationalen Papyrologenkongresses, hg. v. Emil Kiessling, Hans-Albert Rupprecht (München: C.H. Beck, 1974), 169-177; John Philip Thomas, Private Religious Foundations in the Byzantine Empire (Wahington: Dumbarton Oaks, 1987), 66-69; Peter van Minnen, „Medical Care in Late Antiquity”, Clio Medica 27 (1995): 161-163; Adam Sarfass, „Wine for Widows: Papyrological Evidence for Christian Charity in Late Antique Egypt”, $\mathrm{w}$ Wealth and Poverty in Early Church and Society, red. Susan Holman (Grand Rapids: Academic Baker, 2008), 96, 98, 100; Hiltbrunner, „Krankenhaus”, 897. Na temat fundacji chrześcijańskich instytucji dobroczynnych we wczesnobizantyńskim Egipcie, por. Longosz, „Ksenodochium”, 303-308.

75 Van Minnen, „Medical Care”, 161. 


\section{Zarządzanie i ekonomiczne aspekty funkcjonowania chrześcijańskich instytucji szpitalnych w okresie wczesnobizantyńskim}

W relacjach dotyczących interesujących nas instytucji odnajdujemy stosunkowo niewiele informacji na temat zarząazania oraz ekonomicznych aspektów ich funkcjonowania. Brakuje kompleksowych i, co nie mniej ważne, wiarygodnych informacji $\mathrm{w}$ tej mierze. Innymi słowy, nawet jeśli odnotowujemy relacje na temat przekazywania majątków ziemskich, sum pieniężnych lub naturaliów na utrzymanie szpitali bądź ksenodochiów (na przykład zboże i wino, przypadki najczęściej relacjonowane w papirusach z terenu Egiptu), to często nie wiemy, jaka była ich wielkość i czy w ogóle istniały (ta ostatnia uwaga dotyczy części przypadków relacjonowanych we wczesnobizantyńskich tekstach hagiograficznych). Oczywiście wyjątek stanowią szpitale, których działalność relacjonują teksty papirusowe choć i ten materiał poznawczy nie jest wolny od pewnych ograniczeń poznawczych.

Co wiemy na temat zarządzania tego typu instytucjami? Kwestia organizacji szpitali oraz innych chrześcijańskich instytucji dobroczynnych pojawia się w jednym $\mathrm{z}$ arabskich kanonów soboru nicejskiego (obradował w 325 r.) jako zalecenie, aby w każdym biskupstwie był co najmniej jeden ksenodocheion. Z przekazu nie wynika jednak, jak w praktyce miało wyglądać realizowanie tego zadania. Poza tym, co w tym przypadku najważniejsze, nie wiemy, kiedy powstał ten zbiór dokumentów, nie jest on bowiem tożsamy z greckimi aktami soboru nicejskiego. Faktem jednak jest, że w przypadku fundacji znajdujących się pod zarządem kościelnym funkcje nadzorcy z reguły sprawował zaufany prezbiter lub prezbiterzy ${ }^{76}$ (jak w przypadku konstantynopolitańskich szpitali, które pod tym względem zapewne nie były wyjątkiem $)^{77}$ czy też diakon ${ }^{78}$. W instytucjach szpitalnych, przytułkach i zajazdach dla pielgrzymów prowadzonych przez wspólnoty monastyczne funkcję ich nadzorcy piastował zaufany $\mathrm{mnich}^{79}$, mający talenty organizacyjne oraz potrafiący skutecznie pozyskiwać środki na funkcjonowanie tych instytucji. Z ósmego kanonu soboru w Chalcedonie (451 r.) wynika, że instytucjami tymi czasami kierowali także ludzie świeccy ${ }^{80}$, co najprawdopodobniej zachodziło tylko w przypadku prywatnych fundacji ${ }^{81}$. Instytucja świeckiego zarządcy szpitala lub przytułka rozwinęła się szczegolnie

76 Gregorius Nazianzenus, Epistula 211, PG 37; Chronicon Paschale, PG 92, 722 (Leoncjusz, prezbiter Kościoła antiocheńskiego); Palladius Helenopolitanus, Historia Lausiaca 1,1; 6,5. Por. także Knecht, System, 49; Constantelos, Byzantine Philantropy, 149 i n., 216 i n.

77 Joannes Chrysostomus, Dialogus 5.

78 Palladius, Historia Lausiaca 40, 3; Joannes Chrysostomus, Ad Stagyrium III, 13; PG 47; idem, De sacerdotio III, 12, 15.

79 Concilium Chalcedonense, canon 8.

80 Ibidem. Por. także Knecht, System, 49.

81 Codex Iustinianus I, 2, 15. 
w Egipcie w VI oraz na początku VII w. ${ }^{82}$ Nosokomos lub ksenodochos, zarządca podległej sobie placówki, przede wszystkim był odpowiedzialny za gospodarowanie środkami finansowymi gromadzonymi na jej funkcjonowanie. Co ciekawe jednak, osobą, przed którą taki funkcjonariusz zdawał sprawozdanie, także w przypadku prywatnych fundacji świeckich, był miejscowy biskup. Ustawodawca wyszedł w tym przypadku, jak również w analogicznych, z założenia, że miejscowy biskup, osoba godna zaufania, będzie najlepszym sędzią dysponowania środkami przeznaczonymi na prowadzenie instytucji charytatywnej ${ }^{83}$. W praktyce jednak bywało z tym różnie, a sami biskupi nierzadko dopuszczali się na tym polu nadużyć.

Co wiemy na temat osobowości prawnej interesujących nas instytucji? Informacje na ten temat pojawiające się w ustawodawstwie justyniańskim swego czasu zebrali i omówili August Knecht ${ }^{84}$ i Hans Richard Hagemann ${ }^{85}$ i w zasadzie niewiele można już dopowiedziećs ${ }^{86}$. Regulacje dotyczące wszelkich aspektów organizacji i funkcjonowania szpitali, przytułków oraz ksenodochiów znajdują się w pierwszej księdze Codex Iustinianus, w rozdziałach 2 i 3, oraz w Novelae Iustiniani, 120 i 123 . Z zapisów tych wynika, że dopiero w czasach Justyniana interesujące nas instytucje, mimo że nadal miały nad sobą nadzór biskupi, uzyskały autonomię majątkową ${ }^{87}$. Dopiero wtedy posiadane przez nie zaplecze ekonomiczne zostało wyłączone $z$ majątku lokalnych biskupstw ${ }^{88}$. Pewnie nie bez przyczyny tak zadecydowano, a przypadki relacjonowane chociażby przez Palladiusza z Helenopolis dotyczące sporów wokół darowizn dla jednego $\mathrm{z}$ aleksandryjskich szpitali, które w latach dziewięćdziesiątych IV w. toczył prezbiter Izydor z miejscowym patriarchą Teofilem, tylko potwierdzają, iż problem nie był jednostkowy i aby mu zaradzić, wprowadzono wspomnianą powyżej regulację.

W jaki sposób pozyskiwano środki na prowadzenie instytucji dobroczynnych? Jak wielkie były to sumy oraz na jakie konkretne przedsięwzięcia je przeznaczano? Jako że zakładanie, a przede wszystkim funkcjonowanie tego typu instytucji generowało ogromne koszty, najważniejsze były w tym przypadku pokaźne darowizny, często jednak określane dość lakonicznie ${ }^{89}$, nawet wówczas gdy podana jest konkretna suma, żeby przytoczyć tylko relację Palladiusza w Historia Lausiaca na temat anonimowej „bogatej dziewicy” z Aleksandrii. Jeden z tamtejszych

82 Sarfass, „Wine for Widows”, 98-100; Van Minnen, „Medical Care”, 161-163.

83 Codex Iustinianus I, 3, 42, 8. Por. także Longosz, „Ksenodochium”, 321-328.

${ }^{84}$ Knecht, System, 43-55.

85 Hans Richard Hagemann, „Die rechtliche Stellung der christlichen Wohltätigkeitsanstalten in der östlichen Reichshälfte", Revue international des droits de l'antiquité 3 (1956): 265-283.

86 Hiltbrunner, „Krankenhaus”, 894; Longosz, „Ksenodochium”, 333-324.

87 Ibidem. Kötting, Peregrinatio religiosa, 383-384.

88 Novellae Iustiniani 120, 6. Por. także Knecht, System, 46.

89 Hieronymus, Epistula 108, 14; Palladius, Historia Lausiaca 54-55, 6. Por. także przypadek Saby, jednego z współtwórców monastycyzmu palestyńskiego. Spadek znacznych rozmiarów, który przypadł mu po zmarłych rodzicach, przeznaczył on na zakup budynku, który następnie przebudowano na ksenodochium, por. Cyrillus Scythopolitanus, Vita Sabae, 25-31. 
prezbiterów, Makary, wykonujący wcześniej zawód kabidariosa (szlifierza kamieni szlachetnych), pod pretekstem okazyjnego zakupu dlań „szlachetnych kamieni” miał od wspomnianej kobiety „wyłudzić” 500 solidów. Powierzoną mu sumę przeznaczył na bieżące potrzeby prowadzonego przez siebie szpitala, zorganizowanego w dwukondygnacyjnym budynku. Chore kobiety (w tym przypadku określone jako „hiacynty”) były umieszczone na piętrze, mężczyźni zaś (nazwani „szmaragdami") na parterze. Co oczywiste, konwencja dzieła hagiograficznego wymagała, aby zawstydzona podstępem „skąpa dziewica” nie tylko nie zażądała zwrotu wspomnianej sumy, ale też chwytającym za serce przykładem została zachęcona do większej ofiarności. Autor relacji, Palladiusz z Helenopolis, nie podaje jednak żadnych informacji na temat wielkości opisanego szpitala (liczby pensjonariuszy bądź tóżek $)^{90}$.

Na bieżące potrzeby szpitali i przytułków zbierano również pieniądze podczas codziennej lub cotygodniowej kolekty, jak to opisał chociażby Jan Chryzostom, zachęcający swych wiernych do wzmożonej ofiarności na ten cel $^{91}$. Wiarygodne informacje dotyczące ekonomicznych aspektów funkcjonowania interesujących nas instytucji dostarczają teksty papirusowe. W tej mierze ciekawa jest dokumentacja dotycząca fundacji w nabatejskiej Petrze. W dokumencie datowanym na $573 \mathrm{r}$. odnajdujemy informacje na temat darowizn pieniężnych przekazanych na rzecz lokalnego szpitala prowadzonego przez tamtejszego prezbitera, niejakiego Arona ${ }^{92}$.

Co oczywiste, dla codziennego funkcjonowania szpitala ważne były również darowizny w naturaliach. O takowych donosi przede wszystkim materiał papirusowy z Egiptu, zestawiony chociażby przez Adama Sarfassa. Wynika z niego, że tamtejsze szpitale prywatne w połowie VI w. otrzymywały jednorazowo następujące darowizny w zbożu: 371 artab (szpital w Oxyrynchos), 29 artab (kolejny szpital w Oxyrynchos) oraz siedem artab (szpital w Leukadios) ${ }^{93}$. Wielkość wspomnianych darowizn jest więc zróżnicowana. W tym samym materiale nie odnotowujemy natomiast żadnych informacji dotyczących wielkości szpitali, które były beneficjentami przekazywanych naturaliów.

Szpital oraz inne instytucje dobroczynne korzystały, choć w różnym stopniu, także ze środków przekazywanych przez lokalnych biskupów. Ten fakt bywa eksponowany w tekstach hagiograficznych w przypadku tytułowych bohaterów. Czy znaczy to, że miejscowi biskupi nie zawsze wystarczająco wspierali prowadzone pod ich patronatem szpitale oraz inne instytucje dobroczynne? Takie przypadki miały miejsce, a informacje na ten temat pojawiają się wśród zarzutów depozycyjnych

90 Palladius, Historia Lausiaca 6, 5-9.

91 Joannes Chrysostomus, In Mattheum 66, 3-4, PG 58. Por. także Paul Chrysostomus Baur, Der heilige Johannes Chrystsomus und seine Zeit, Bd. 1 (München: Hueber, 1930), 55; Kötting, Peregrinatio religiosa, 383. Hiltbrunner, „Krankenhaus”, 898.

${ }_{92}$ Jakko Frösén, „The Petra Papyri. Information and Significance”, w idem, Zbigniew Fiema, Petra. A City Forgotten and Rediscovered (Helsinki, 2002), 18-24.

93 Sarfass, „Wine for Widows”, 98-100. 
formułowanych pod adresem sądzonych biskupów ${ }^{94}$. Tak jak wspomniałem powyżej, we wczesnobizantyńskich tekstach hagiograficznych eksponowane są przede wszystkim przejawy szczodrości, bez wyjątku w przypadku bohaterów pozytywnych, którzy nierzadko, co jest wyraźnie akcentowane przez autorów relacji, działali wbrew woli swych kościelnych zwierzchników, żeby przytoczyć chociażby przykład prezbiterów Kościoła aleksandryjskiego pod rządami biskupa Teofila. Patriarsze zarzucano, że nie raz czynił zakusy, aby zagarnąć środki, które aleksandryjscy chrześcijanie przekazywali na funkcjonowanie miejscowych szpitali. Wedle relacji Palladiusza Teofil, chcąc przejąć te fundusze, nie cofał się nawet przed oskarżeniem swego ksenodochosa, prezbitera Izydora, o przywłaszczenie pieniędzy, rzekomo „tysiąca solidów”, które na potrzeby miejscowych biedaków ofiarowała jedna $\mathrm{z}$ zamożnych chrześcijanek ${ }^{95}$. Zarzut, co oczywiste, $\mathrm{w}$ tym przypadku był nieprawdziwy, a miejscowi chrześcijanie, znając uczciwość i oddanie dla sprawy wspomnianego Izydora, nie dali wiary zarzutom formułowanym przez patriarchę. Ale czasami również ekonomowie biskupi pełniący funkcję ksenodochosa (względnie nosokomosa) dopuszczali się nadużyć na tym polu. Kiedy Chryzostom objął w 398 r. rządy biskupie w Konstantynopolu, za radą swych stronników przeprowadził kontrolę kościelnych ksiąg finansowych. Pośród wielu wykazanych przy tej okazji nieprawidłowości czytamy, że prezbiterzy tamtejszego Kościoła pełniący funkcje ekonomów i zarządców miejscowych szpitali za czasów jego poprzednika, biskupa Nektariosa, przywłaszczyli sobie spore sumy, znacznie zawyżając koszty funkcjonowania tych instytucji ${ }^{96}$.

Choć przypadki malwersacji finansowych nie były rzadkie, to pewnie równie często zdarzały się także sytuacje wzorcowe, co kolejny raz potwierdza przykład opisany przez Jana Chryzostoma. Wspomniana już powyżej kontrola finansowa doprowadziła nie tylko do wykrycia licznych nieprawidłowości, ale również do reorganizacji sposobu zarządzania interesujących nas tu instytucji w stolicy. Palladiusz z Helenopolis, opisując działalność dobroczynną swego bohatera, daje również wgląd w organizację tamtejszych szpitali oraz przytułków. Poza wyspecjalizowanym personelem medycznym i kucharzami czytamy także o personelu pomocniczym, rekrutującym się spośród zaufanych świeckich ${ }^{97}$. Ci ostatni pewnie byli opłacani, choć nie jest mi znana jakakolwiek relacja dotycząca tego typu uposażeń w okresie wczesnobizantyńskim.

94 Por. chociażby przypadek Antoninusa, biskupa Efezu, por. Palladius, Dialogus 13, 163-176. Por. także Dagron, Naissance, 467-468; Ireneusz Milewski, Depozycje i zsyłki biskupów w Cesarstwie Wschodniorzymskim (lata 325-451) (Gdańsk: Wydawnictwo Uniwersytetu Gdańskiego, 2008), 144-146.

${ }_{95}$ Palladius, Dialogus 6, 58, 95. Por. także Edward Dawid Hunt, Holy Land Pilgrimage in the Later Roman Empire: AD 312-460 (Oxford: Oxford University Press 1984), 466, 472.

96 Palladius, Dialogus 5.

97 Ibidem. 
Kwestia personelu chrześcijańskich instytucji dobroczynnych u schyłku antyku jest dobrze znana historykom głównie ze względu na wspomnianych już powyżej aleksandryjskich parabollani, którzy uchodzili również za zbrojne ramię tamtejszych biskupów, Teofila, a następnie Cyryla. Ich liczba wahała się od 500 do 600 członków, a przed wydarzeniami 415 r. (antyżydowskie i antypogańskie rozruchy w Aleksandrii, których ofiarą padła między innymi Hypatia) liczba ta pewnie była znacznie większa ${ }^{98}$. Kiedy po wspomnianym tumulcie cesarz Teodozjusz II ograniczył ich liczbę do $500^{99}$, już w roku następnym w specjalnym rozporządzeniu adresowanym do prefekta miasta zwiększył jednak ich liczbę do 600, argumentując swoją decyzję personalnymi wakatami w aleksandryjskich szpitalach ${ }^{100}$.

O kolejnym przypadku biskupiej szczodrości czytamy w Vita Rabulae. Rabula z Edessy (zm. 435 r.) doskonale zdawał sobie sprawę z faktu, że szpital jest niezbędny w mieście, w którym był biskupem. Wiedząc zaś o permanentnych brakach środków na jego prowadzenie, podjął decyzję o wydzieleniu części majątku z dóbr należących do biskupstwa i przeznaczania całości uzyskiwanego zeń dochodu na funkcjonowanie miejscowego nosokomeionu. Według anonimowego autora przekazu uzyskiwana suma gwarantowała coroczny przychód w wysokości tysiąca sztuk srebra ${ }^{101}$. Także nowo zakładane instytucje dobroczynne w Aleksandrii na początku VII w. (w tym szpitale) były sowicie wspierane przez miejscowego biskupa, Jana Jałmużnika ${ }^{102}$.

Omawiając ekonomiczne aspekty funkcjonowania nosokomeionów i przytułków we wczesnym Bizancjum, należy nieco uwagi poświecić wątpliwościom co do bliżej nieokreślonych obciążeń fiskalnych, do których płacenia były one $\mathrm{w}$ pewnym okresie zobligowane. To jeden z bardziej kłopotliwych problemów związanych z funkcjonowaniem interesujących nas instytucji, szczególnie w IV w. Przekazy na ten temat są niejasne, jednostronne, powiedzielibyśmy, że przypisujące złą wolę lokalnym urzędnikom podatkowym, czego w niektórych przypadkach rzeczywiście nie można wykluczyć. W czym więc tkwił problem? Przede wszystkim w tym, że do czasów Justyniana interesujące nas instytucje nie miały unormowanej sytuacji prawnej, a lokalni biskupi oraz zarządcy przytułków i szpitali w coraz intensywniej chrystianizującym się Imperium Rzymskim stali na stanowisku, iż skoro w instytucjach tych prowadzi się działalność dobroczynną i czyni uczynki miłosierne, to nie powinny być one obciążone jakimikolwiek zobowiązaniami podatkowymi. Komasowane zaś przez te instytucje majątki ziemskie oraz uzyskiwany zeń dochód umożliwiały funkcjonowanie wspomnianym instytucjom. Problem w tym, że taka kategoria podmiotów zwolnionych $\mathrm{z}$ różnorakich

98 Problem aleksandryjskich parabollani ma obszerną literaturę. Najważniejsze pozycje w tej mierze do 1997 r. zestawia: Longosz, „Ksenodochium”, przyp. 288.

99 Codex Theodosianus XVI, 2, 43.

100 Codex Iustinianus I, 3, 18. Por. także Knecht, System, 49; Longosz, „Ksenodochium”, 326-327.

101 Vita Rabulae, 205-206.

102 Leontios Neapoleos, Vita s. Joannis Elemosynarii 1, 6. 
obciążeń fiskalnych nie istniała w rzymskim prawodawstwie drugiej połowy IV w., a lokalni urzędnicy podatkowi lub też namiestnik, od którego patroni lokalnych szpitali i ksenodochiów domagali się odstąpienia od poboru podatków, nie miał narzędzi prawnych, aby przychylić się do takiej prośby. Taka przesłanka zachodziła tylko w przypadku katastrof naturalnych (susza, powódź, trzęsienie ziemi), ale nawet wtedy podatnik (w tym miasta, prowincje lub ich części) mógł liczyć co najwyżej na odwleczenie terminu płatności, czasami na zmniejszenie podatku, ale nigdy na jego anulowanie w całości „po wsze czasy”, czego domagali się ówcześni duchowni dla wspomnianych instytucji dobroczynnych działających na terenie ich biskupstwa (chociażby Bazyli Wielki czy Grzegorz z Nazjanzu) ${ }^{103}$. We wczesnobizantyńskich relacjach źródłowych odnajdujemy w zasadzie tylko dwa przekazy dotyczące obciążeń podatkowych spoczywających na chrześcijańskich instytucjach dobroczynnych i chyba nie jest to dziełem przypadku. W związku z tą kwestią mamy wgląd w nieco szersze zjawisko, które pojawiło się u schyłku antyku w całym Cesarstwie Rzymskim, także na Zachodzie. Chodzi mianowicie o pozbawienie państwa dochodów $\mathrm{z}$ różnorakich podatków związanych z posiadaniem nieruchomości w momencie przekazania ich lokalnemu biskupstwu, w tym na działalność miejscowych instytucji dobroczynnych. $Z$ tą chwilą państwo pozbawiało się jakiegokolwiek dochodu z przekazanego majątku. Tak jak od połowy IV w. funkcjonowało swego rodzaju niepisane prawo, aby z tego typu instytucji nie ściągać podatków (ze względu na prowadzoną w nich działalność dobroczynną), tak już za rządów cesarza Walensa (364-378) sprawa nie była wcale tak oczywista w przypadku przytułku bądź szpitala funkcjonującego na obszarze jurysdykcji biskupa należącego do stronnictwa (np. nicejczyków), które nie było wówczas popierane przez państwo (cesarza). Najprawdopodobniej tego typu sytuację obrazuje korespondencja wspomnianych już wyżej biskupów kapadockich z drugiej połowy IV w.: Bazylego, biskupa Cezarei, oraz Grzegorza, biskupa Nazjanzu. Bazyliada to nie jedyna fundacja interesującego nas typu pod jurysdykcją biskupa Cezarei. O kolejnych, choć dość ogólnikowo, dowiadujemy się z dwóch jego listów, w których prosi on lokalnych poborców podatkowych o zwolnienie z bliżej nieokreślonych obciążeń fiskalnych ${ }^{104}$. Wniosek $\mathrm{z}$ tego taki, że wspomniane instytucje również posiadały pewien majątek. Poza tym, co w tym przypadku jest nie mniej ważne, Bazyli był jednym z „walczących” liderów nicejczyków na Wschodzie, na których niechętnie patrzył rządzący tam cesarz Walens. Z tego też względu nie można wykluczyć, iż odmowa przywilejów podatkowych w tym konkretnym przypadku to również jedno z narzędzi, po jakie sięgał cesarz arianin w walce $\mathrm{z}$ wpływami nicejczyków na Wschodzie. $Z$ drugiej zaś strony pogardliwe odnoszenie się do Walensa nie przeszkadzało tym samym duchownym domagać się od państwa, w tym przypadku od cesarza, przywilejów podatkowych

103 Johannes Karayannopulos, Das Finanzwesen des frühbyzantinischen Staates (München: Verlag Richard Oldenbourg, 1958), 188-197

104 Basilius Magnus, Epistulae 142-143, PG 32. Por. także Van Dam, Kingdom of Snow, 77-94. 
dla przedsięwzięć dobroczynnych, którym patronowali. Problem wspomnianych zwolnień podatkowych był zapewne jednak większy. Rozciągnięcie płynących z tego dobrodziejstw na wszystkie instytucje dobroczynne w tym czasie generowałoby spore szkody w cesarskim skarbcu. Poza tym nie można wykluczyć pewnej patologii, polegającej na fikcyjnym zapisywaniu majątków ziemskich chrześcijańskim instytucjom dobroczynnym tylko po to, aby uwolnić je od wszelkich obciążeń podatkowych. Co oczywiste, informacji na ten temat nie odnajdziemy w korespondencji ówczesnych biskupów. Pewne nawiązanie do tej kwestii odnajdujemy natomiast w ustawodawstwie justyniańskim. Wiele instytucji dobroczynnych dzięki szczodrym zapisom wiernych stawało się posiadaczem i administratorem sporych majątków, którymi trzeba było odpowiednio zarządzać, tak aby przysparzały one zysk przeznaczany na funkcjonowanie lokalnych instytucji dobroczynnych. Komasowane majątki to nie tylko zysk, ale również konieczność gospodarowania nimi, a w tym przypadku, jak potwierdzają to prawa justyniańskie, czasami wybierano najprostszą drogę, bez dbałości o kondycję ekonomiczną Cesarstwa. We wspomnianych rozporządzeniach Justyniana czytamy, że zarządcy interesujących nas instytucji dowolnie i bez żadnej kontroli dysponowali majątkiem nieruchomym, wydzierżawiając go lokalnym obszarnikom wraz z przypisanymi do areału mieszkańcami, kolonami. Wydzierżawiany w takiej sytuacji majątek przynosił dochód nie tylko ksenodochium czy nosokomium, ale również dzierżawcy, który znacznie taniej dzierżawiąc go od instytucji kościelnej (mogła sobie na to pozwolić, ponieważ nie płaciła z tytułu posiadania konkretnego majątku jakichkolwiek podatków), również nie uiszczał podatku. Jedynym podmiotem ponoszącym uszczerbek finansowy było państwo, niemające udziału w zyskach $\mathrm{z}$ gospodarowania wspomnianym majątkiem ${ }^{105}$.

Okazję do pojawienia się różnorakich nadużyć finansowych stwarzały również okoliczności i czas pozyskiwania przez instytucje, a czasami przez zarządców majątku, nieruchomości czy też sum pieniężnych. Co prawda, ustawodawstwo justyniańskie z pewnych względów, których można się tylko domyślać, nie nazywa towarzyszącej temu patologii po imieniu. $Z$ brzmienia konkretnych zapisów można jednak wywnioskować, jakie nadużycia lub co najmniej pewna „dwuznaczność” towarzyszyły czasami nabywaniu majątków przez interesujące nas instytucje. Gorliwi w wierze wierni, przekazując darowiznę za życia lub w zapisach testamentalnych, nie zawsze doprecyzowali jej odbiorcę, nie zawsze jednoznacznie wskazywali, że majątek ma zostać przeznaczony na funkcjonowanie konkretnej instytucji. Czasami jako dziedzica ustanawiano nadzorcę miejscowego przytułku bez doprecyzowania, kto miał być rzeczywistym beneficjentem: nadzorca (jako osoba prywatna) czy też zarządzana przez niego instytucja. Pewnie nie raz w tej kwestii pojawiały się różnorakie „niedopowiedzenia” i wypływające z nich zadrażnienia, stąd ingerencja Justyniana, który specjalnym rozporządzeniem orzekł, że wszelki majątek przekazany nawet imiennie zarządcom szpitali, przytułków

105 Codex Iustininus I, 2, 19; 22; 23; I, 3, 227; 34. Por. także Novelae Iustianiani 7, 1; 9, 12. 
lub ksenodochiów przez osoby postronne winien przypaść prowadzonym przez nich instytucjom. Wyjątkiem były zapisy, jakie wspomniani nadzorcy dziedziczyli po swych krewnych ${ }^{106}$.

Wróćmy jednak do kwestii obciążeń fiskalnych spoczywających na majątkach ziemskich przekazywanych instytucjom dobroczynnym. W podobnych sprawach, jak Bazyli, biskup Cezarei Kapadockiej, do lokalnych urzędników podatkowych zwracał się Grzegorz z Nazjanzu (lata osiemdziesiąte IV w.). Pisał on w imieniu nadzorcy pewnego przytułku z prośbą o zwolnienie od wszelkich podatków spoczywających na dwóch posiadłościach, które podarował mu bliżej nieznany Kastor ${ }^{107}$. Niestety nie znamy finału tej interwencji, a fakt, że w zbiorze listów Grzegorza nie zachowały się kolejne pisma w tej sprawie, nie musi oznaczać, iż została ona załatwiona pozytywnie dla miejscowego przytułka. Orientując się w metodach zwalczania przez państwo nicejczyków w czasach Walensa, nie można wykluczyć, że wspomniane trudności w przypadku przytułków nadzorowanych przez Bazylego rzeczywiście podyktowane były polityką kościelną cesarza. Przypadek relacjonowany przez Grzegorza z Nazjanzu potwierdza jednak, iż nie można wykluczyć tu również innej kwestii. Mówimy tu bowiem o instytucjach, które miały świadczyć pomoc przede wszystkim „swoim”, nicejskim chrześcijanom, a wykluczać z niej nie tylko pogan i żydów, ale również tzw. heretyków. Julian Apostata, zachwalając w jednym ze swoich listów przytułki prowadzone przez chrześcijan, wspomina co prawda, że opiekę znajdowali w nich również poganie ${ }^{108}$, niemniej z jednego z listów Teodora z Mopsuestii zdaje się wynikać zupełnie coś przeciwnego. Czytamy w nim, iż kierując się zaleceniami św. Pawła, należy wspierać tylko „braci w wierze”109. W niemalże identycznym tonie utrzymane jest zalecenie Jana Chryzostoma, sformułowane w traktacie De sacerdotio. Wynika z niego, że „niegodni” (a pod tym pojęciem rozumie on wszystkich tych, którzy „znieważają Chrystusa”) nie powinni być objęci jakimkolwiek kościelnym wsparciem ${ }^{110}$. W tej mierze jednak Chryzostom charakteryzuje się pewną niekonsekwencją, gdyż w innym ze swoich pism przywołuje przykład „miłosiernego Samarytanina”, stawiając go za wzór pomocy wolnej od jakichkolwiek uprzedzen ${ }^{111}$. Tej swoistej „selekcji” podróżnych, rozróżniania pomiędzy ortodoksyjnym chrześcijaninem i heretykiem, miały służyć tzw. listy polecające, wystawiane przez biskupów swym wiernym udającym się w podróż ${ }^{112}$. Przypuszczam jednak,

106 Codex Iustinianus I, 3, 4, 11; I, 3, 32. Por. także analogiczny zapis w Novelae Iustiniani 131, 15.

107 Gregorius Nazianzenus, Epistula 211. Por. także Van Dam, Kingdom of Snow, 77-94.

108 Julianus, Epistula 39 (84). W tej kwestii por. także Constantelos, Byzantine Philantropy,

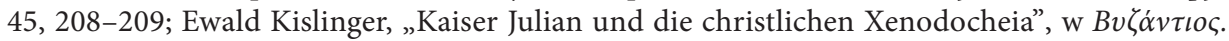
Festschrift für Herbert Hunger zum 70. Geburtstag, hg. v. Wofrman Hörandner (Wien: Erwin Becvar, 1984), 171-184; Hiltbrunner, „Krankenhaus”, 900.

109 Theodorus Mopsuestenus, In epistolam ad Timitheum I 3, 2. Por. także Longosz, „Ksenodochium", 328.

110 Joannes Chrystsomus, De sacerdotio III, 12, 15.

111 Joannes Chrysostomus, In Psalmos 143, 3, PG 55.

112 Knecht, System, 47; Kötting, Peregrinatio religiosa, 184, 378; Longosz, „Ksenodochium”, $328-330$. 
że większość podróżnych i tak nie była w ich posiadaniu, a zdrożonemu lub choremu poganinowi, żydowi bądź „,heretykowi” w niespokojnej okolicy w czas niepogody lub nocą pewnie i tak nie odmawiano pomocy.

Co wiemy na temat wielkości instytucji dobroczynnych? Podstawą do ustaleń w tej mierze są przekazy dotyczące konkretnych fundacji. W większości przypadków trudno zweryfikować ich zasadność. Nieco informacji w tej mierze przynoszą wyniki prac archeologicznych oraz oględzin terenowych w miejscach, w których w okresie wczesnobizantyńskim funkcjonowały interesujące nas instytucje. Tak jak sygnalizowaliśmy powyżej, problem $\mathrm{z}$ informacjami dotyczącymi ekonomicznych aspektów funkcjonowania wczesnobizantyńskiego szpitalnictwa polega na tym, że brakuje kompleksowych i co najważniejsze, wiarygodnych relacji na ten temat. Innymi słowy, nawet jeśli odnotowujemy relacje, w których mówi się o przekazaniu pewnych sum pieniężnych lub naturaliów (zboża i wina) na rzecz konkretnego szpitala, to $\mathrm{z}$ reguły nie wiemy, jaka była jego wielkość. Wyjątkiem jest tu przekaz Cyryla z palestyńskiego Scytopolis. Czytamy w nim, że cesarz Justynian sfinansował budowę nosokomeionu „na sto łóżek” w Jerozolimie oraz zagwarantował środki na jego utrzymanie. W pierwszym roku miała być to suma 1850 solidów, w kolejnym zaś szpital miano rozbudować o dalsze sto łóżek przy jednoczesnym utrzymaniu zadeklarowanego finansowania przez cesarza ${ }^{113}$. Tyle przekaz Cyryla. Czy jest on wiarygodny? Tu miałbym pewne wątpliwości, nie tyle w kwestii sumy, co do wielkości fundacji (liczba łóżek). Wszelkie dane, jakie odnajdujemy w greckich tekstach hagiograficznych z zastosowaniem cyfr: 1 i 3, jak również liczb: 10, 30, 100, 300, 1000 lub też 3000, należy odrzucić, są to bowiem $\mathrm{z}$ reguły wielkości i wartości topiczne, dane mijające się z prawdą. Podobnie jest $\mathrm{z}$ informacjami zaczerpniętymi z greckiego kręgu kulturowego, przejętymi przez autorów łacińskich. Zasadność tego stwierdzenia potwierdza chociażby informacja dotycząca palestyńskich fundacji w VI w., odnaleziona u Anonima z Piacenzy. W swym opisie pielgrzymki do Ziemi Świętej wspomina on o zajeździe dla pielgrzymów usytuowanym przy bazylice Najświętszej Marii Panny w Jerozolimie. Elementem tego kompleksu był również szpital, wyposażony rzekomo aż w „trzy tysiące łóżek" ${ }^{114}$. Teoretycznie jest to oczywiście możliwe, ale wspomniana fundacja to jedna $\mathrm{z}$ wielu, które w tym czasie istniały w Jerozolimie, i raczej wątpię, aby tylko ona miała tak wiele łóżek dla chorych, skoro już ufundowanie szpitala na sto łóżek oraz zabezpieczenie jego finansowania w kolejnych latach było iście „cesarską" fundacją. Innymi słowy, znając skłonności ówczesnych autorów greckich bądź też autorów łacińskich działających na terenie greckiego obszaru kulturowego (Hieronim ze Strydonu, Jan Kasjan) do pewnej przesady w podawaniu cyfr i liczb, powyższą informację Anonima z Piacenzy trzeba postrzegać tylko jako potwierdzenie funkcjonowania sporego szpitala przy wspomnianej bazylice. Poza tym pamiętać należy, że wszelkie „okrągłe” liczby bądź sumy pieniężne z reguły nie zasługują na wiarygodność.

113 Cyrillus Scythopolitanus, Vita Sabae 73.

114 Anonymus Placentinus, Itinerarium 23. 
$\mathrm{W}$ relacjach pochodzących $\mathrm{z} \mathrm{V}$ w. odnajdujemy kolejne informacje dotyczące wielkości szpitali: „około 300 łóżek” w Edessie czasów Efrema (początek drugiej połowy IV w.) oraz 70 łóżek w Efezie połowy V w. ${ }^{115}$ Tak jak pierwsza z przytoczonych informacji jest wątpliwa (topiczny charakter podanej liczby), tak nie ma potrzeby kwestionowania tej drugiej, została ona bowiem zapisana w aktach soboru chalcedońskiego ${ }^{116}$. Także Peter van Minnen w swych wyliczeniach dotyczących wielkości prywatnych szpitali w Egipcie w połowie VI w. (w Arsinoe oraz Hermopolis) dochodzi do wniosku, że z reguły liczyły one do 50 łóżek ${ }^{117}$.

Tam gdzie brak relacji pisanych, czasami z pomocą przychodzą wyniki oględzin terenowych. Badania przeprowadzone w Deir Siman, antycznym Telanisssos, udowodniły, że niektóre z ksenodochiów przylegających do tamtejszego sanktuarium Szymona Słupnika ${ }^{118}$ posiadały izby mogące pomieścić około 70 łóżek ${ }^{119}$. Jeszcze większe pomieszczenia zlokalizowano w miejscowości Turmanin, przy szlaku prowadzącym do klasztoru sławnego stylity. Szacuje się, iż tamtejsze jednokondygnacyjne ksenodochia mogły pomieścić nawet do 400 podróżnych ${ }^{120}$.

\section{Zakończenie}

Większość informacji dotyczących ekonomicznych aspektów funkcjonowania szpitali w okresie wczesnobizantyńskim odnalezionych w tekstach literackich jest dość lakoniczna, obfituje w stwierdzenia, że ten czy inny "miejscowy bogacz”, czasami wzmiankowany nawet $\mathrm{z}$ imienia, przekazał cały swój majątek lub tylko jego część na miejscowy szpital. Rzadko natomiast podawane są konkretne sumy pieniężne, a już tym bardziej darowizny z określeniem wielkości obdarowanej instytucji. Analogiczna przypadłość charakteryzuje również teksty papirusowe obrazujące funkcjonowanie prywatnych szpitali w Egipcie VI w. Nawet jeśli odnajdujemy w nich szczegółowe informacje dotyczące wysokości przekazywanych darowizn (najczęściej w naturaliach: w zbożu oraz w winie, rzadko w pieniądzu), z reguły nie wiemy, jak wielki był obdarowywany szpital, a wszelkie wyliczenia w tej mierze (także cytowane powyżej autorstwa Petera van Minnena) mają charakter mniej lub bardziej zasadnych spekulacji.

\footnotetext{
115 Palladius, Historia Lausiaca 40, 3.

116 ACO 2, 1, 405.

117 Van Minnen, „Medical Care”, 161.

118 Evagrius, Historia Ecclesiastica I, 14. Por. także Tschalenko, Vilages antiques, 208-210; Kötting, Peregrinatio religiosa, 124-130; 381.

119 Henri Leclercq, „Hôpitaux, hospices, hotelleries”, w Dictionaire d'Archeologie Chretienne et de Liturgie, t. 6/2 (Paris: Letouzey et Ané 1907), 2755-2757; Kötting, Peregrinatio religiosa, 380-382; Lionel Casson, Podróże w starożytnym świecie (Wrocław: Ossolineum, 1981), 223-231.

120 Leclercq, „Hôpitaux”, 2751-2757; Kötting, Peregrinatio religiosa, 381-382; Longosz, „Ksenodochium", 330-333.
} 
Ireneusz Milewski

\section{Economical aspects of nosokomeia in early Byzantium}

In the $4^{\text {th }}$ century, an époque of intensive Christianisation of the Roman Empire, a new form of providing aid to fellow neighbours appeared, namely charity organizations. Although there were several types of them, in practice the differences between them were quite seamless. Depending on needs, hospital functions were carried by ksenodochia (inns for Christian pilgrims and other travellers), ptochotrophia (shelters for the poor), gerokomia (homes for the elderly) and most of all nosokomia specialised in treating the sick. Also, the Church legislator of the time (synods and councils) and the secular lawmaker (the emperor) did not differentiate the scope of activities of the aforementioned institutions. Since the sick, the poor or pilgrims (or any other exhausted travellers), no matter their age, were able to find shelter or help in each of those institutions, they were commonly perceived as identical. The sources we have, however, do not provide an answer to the question of how this issue was regulated in practice, if only due to the prevention against spreading various diseases (separating the contagiously ill, including most of all lepers, from less severe cases). The sources we know do not also provide an explicit answer to another important question, namely whether in such types of Christian charitable institutions also pagans, Jews or even „heretics” were able to find treatment.

Information on the subject of early Byzantine hospitality are found mainly in hagiographic, papyrus or normative texts of the time (mainly in the legislature of emperor Justinian). The geographical range of Christian charitable institutions in the period of our interest is considerably well known, yet it is a different case in terms of attempts to estimate their numbers and size. In that matter, if we were to count individual foundations mentioned in the sources as well as those known from field research, it would turn out that in the whole Eastern Roman Empire only several dozens of such institutions had been functioning since the beginning of the $7^{\text {th }}$ century; numbers, which undoubtedly are considerably underestimated. We already find them since the 20 s of the $4^{\text {th }}$ century in Egypt and later on in Asia Minor, in Syria, Palestine and obviously in the capital of the Eastern Roman Empire, Constantinople. In greatest numbers the Christian charitable institutions were established most of all in large cities or in the case of specialised medical centres such as leprosoria (homes for lepers), in their nearby areas. They were run mostly by the local clergy (presbyterians or deacons) or monks, who would also take care of financing them. Money (as well as other goods) needed for their functioning were collected by means of small contributions and most of all through sizeable donations and last will testaments made by affluent founders. 